\title{
The Future Prospects of Arbuscular Mycorrhizal Fungi in Slope Ecological Restoration
}

\author{
Yujie Yan ${ }^{1,2}$, Bingqin Zhao ${ }^{2}$, Wennian $\mathrm{Xu}^{2}$, Fei Yu${ }^{1,2}$, Wenjing Liu ${ }^{1,2}$, Dong Xia ${ }^{2,3 *}$ \\ ${ }^{1}$ China Three Gorges University, College of Biological and Pharmaceutical Sciences \\ Yichang, Hubei, China \\ ${ }^{2}$ China Three Gorges University, Collaborative Innovation Center for Geo-Hazards \\ and Eco-Environment in Three Gorges, Yichang, Hubei , China \\ ${ }^{3}$ China Three Gorges University, Engineering Research Center of Eco-Environment in Three Gorges Reservoir, \\ Yichang, Hubei, China
}

Received: 12 June 2019

Accepted: 4 August 2019

\begin{abstract}
The rapid development of transportation and urbanization has promoted the continuous innovation of slope ecological restoration technology (SERT). More environmentally friendly and efficient technologies are being developed and perfected to make the restored slopes sustainable and be able to integrate into the natural environment, in which microbial-plant remediation technology was been taken into account. Arbuscular mycorrhizal fungi (AMF), a microbial material commonly used in ecological restoration, has a symbiotic relationship with the majority of terrestrial plants to provide water and nutrients, and has been successfully used in the field of ecological restoration in recent years. Combining stress tolerance and growth promotion for plants with improvement of soils properties through strengthened associations with AMF would help to increase the efficiency of slope ecological restoration. This review mainly introduces AMF research progress in terms of plant stress tolerance, ecological optimization, and symbiosis with plant species for phytoremediation, summarizes the current challenges faced in the application of AMF in ecological restoration projects, and highlights the future research direction for resolving the mentioned problems. Finally, theoretical study and field applications are combined to provide an overview of the future application prospects in slope ecological restoration.
\end{abstract}

Keywords: arbuscular mycorrhiza, ecological restoration, slope engineering, stress tolerance

\section{Introduction}

The rapid development of transportation and urbanization not only provides convenience for human beings but also is destroying the ecosystem [1, 2]. Global attention has focused on restoring damaged

*e-mail: xiadongsanxia@sohu.com ecosystems and making sustainable development choices [3-6]. As the basic unit of ecological damage caused by infrastructure construction, engineering slopes directly affect the quality of the urban ecological environment $[1,3]$. Slope ecological restoration, which aims at assimilating the slope ecological environment into the surrounding natural landscape $[1,2]$, is defined as an artificial restoration combining plant and nonliving materials with civil engineering technology to mitigate slope instability and erosion $[3,7,8]$. Existing 
high-efficiency technologies usually adopt various strengthening facilities or bonding materials to the substrate in order to establish a relatively stable slope [1, $2,9]$. Nevertheless, long-term stability is still hard to be satisfied entirely by a substantial proportion of existing methods, thus microbial-phytoremediation technology is considered for SERT under the demand of sustainable development.

Microbes with the ability to improve the nutrient transmission efficiency of plants and soil make the plantmicrobial technology a global hotspot in the restoration field $[6,10,11]$. Arbuscular mycorrhizal fungi (AMF), the most widely distributed plant symbiotic fungi in nature, are one of the typical representatives [11, 12]. Through the production of their two special structures, vesicles and arbuscules, AMF can provide effective assistance for interaction between plants and fungi by means of delivering soil nutrients to the hosts in return for carbon [5, 10]. A significant amount of research has focused on the function of AMF in ecological restoration, mainly the improvement of plant stress tolerance [4, 13], soil conditions [12, 14, 15], and community structure $[4,16,17]$, indicating that AMF are efficient materials for ecological restoration. Though the application of AMF in the field of soil restoration has proliferated rapidly in recent years [12], efforts in mycorrhizal technology applied to SERT are relatively limited.

This review first summarizes the effects of AMF on plant stress tolerance and slope ecological optimization in theory and then intends to introduce the symbiosis between AMF and pioneer species for phytoremediation in order to ensure the feasibility of the application. Finally, actual problems in project applications are presented in addition to advice and proposals on those problems to overview the future application prospects in slope ecological restoration.

\section{Progress and Challenges of SERT}

\section{Specialization and the Development of SERT}

The earliest embryo of SERT was vegetation slope protection initially used for bank revetment and barren hills control [3, 8]. In the 1930s, SERT was first introduced to Central Europe and has rapidly developed since then [8]. The spray seeding machine developed by an American company in the 1950s realized the mechanization of SERT [18], and the hydraulic seeding technology using emulsified asphalt as a binder was invented in Britain. In the early 1960s, Japan promoted SERT on a large scale through continuous improvement and innovation based on the experience in Europe and America [19]. In the 1980s, while the three-dimensional grass planting technology was widely used in Western countries [20], Japan developed the fiber-soil greening method, which is also the embryonic form of the thick-layer base material spraying method, marking the beginning of a rock greening project $[8,19,21]$. In the intervening years, the soil-flock greening method (1983) and the continuous fibers greening method (1987), which synthesized the continuous reinforced geotechnical method proposed by Henri Vidal [22], were subsequently developed. At the end of the 20th century, Japan developed the permanent greening method of soil microorganisms, which used soil microorganisms to accelerate the soil transformation of rocks, reflecting the important role of soil microorganisms in the process of slope ecological restoration $[8,23]$.

Research on substrate composition, species selection, construction technology and maintenance management of SERT has entered a mature stage [3]. Existing commonly used technologies can be classified according to different habitat construction methods, including: plant direct covering, planting hole construction, reinforced filling and spray sowing [8]. Throughout the history of SERT development, early technologies such as green geonet [24] and vegetated riprap [25] usually establish plant communities or construct planting holes on the slope to create a better surrounding for plant growth [24]. Though less construction technology was required by those methods, the long-term revegetation effect cannot be guaranteed [8]. The later development of SERT combined mechanical reinforcement with vegetation reconstruction [26], and added different types of hard materials and environment-friendly materials [3, 27], more consideration was paid to environmental and biological needs while guaranteeing slope stability.

\section{The Challenges of SERT}

Along with increased requirements for innovative, green, coordinated and sustainable development, SERT is challenged with: how to improve the stress tolerance of the slope system [28], how to strengthen slope safety $[3,26]$, and how to beautify landscaping, adding to the complexity of the implementation.

The construction of infrastructure will create a large amount of excavation slope, disturb the original landform and vegetation, aggravate the deterioration of the ecological environment, and also form a hidden danger of geological disasters. Existing technologies often through the artificial addition of nutrients, or introduce pioneer plants [28], especially shrubs and herbs with developed roots, strong expansibility and ecological functions adapted to local natural vegetation communities in order to improve the stress tolerance of the whole slope system [29], and through rational plant disposition for better landscaping. At the same time, the slope safety factor is strengthened by the construction of reinforcement facilities (reinforced filling methods), laying rock bolts, metal protective nets, or adding bonding materials (spray sowing methods) to the substrate $[3,8,27]$. The series of artificial assistant methods has consumed lots of effort yet the sustainability of its development was still not guaranteed. Faced with these challenges, new technologies such as restoration 
ecology, macromolecule materials and microbiology are combined with slope restoration technology to enhance the restoration effect $[3,8]$. This paper will investigate the role of AMF in overcoming the challenges of SERT, and evaluate its feasibility and advantages.

\section{AMF and Slope Environmental Stress}

\section{Benefits under Physical Stress}

Restoration technique should be adjusted judging from different characteristics of the macro environment, climate characteristics, and other physical factors [7]. The features of these restoration projects, primarily long-distance, large area, and limited time, result in difficulties in conventional manual maintenance [1, 30].

Slopes located in arid and simiarid regions present more difficulties to management due to the low amount of species diversity and the fragile ecological environment brought by low rainfall $[1,7,31]$. Current technologies in arid areas focus on introducing high drought-resistant species or improving the substrate formula by adding super absorbent composite to alleviate water shortage [1], yet those methods only worked effectively in a certain range of time [31, 32]. AMF can be utilized in restoration to improve plant tolerance under drought conditions because of the improvement of plant water utilization efficiency of AMF (Fig. 2) [4, 10, 33]. Previous researchers have proven that plant drought tolerance is enhanced after inoculation by detecting the growth and branching of the root system and the activity of the defense system in plants (Fig. 1) [10, 33]. Seedlings inoculated with AMF had higher antioxidant enzyme (Tyagi et al. 2017) [34], ascorbic acid, glutathione peroxidase [33], glomalinrelated soil protein (GRSP), soluble sugar contents [34], nutrient uptake efficiency (especially nutrients with

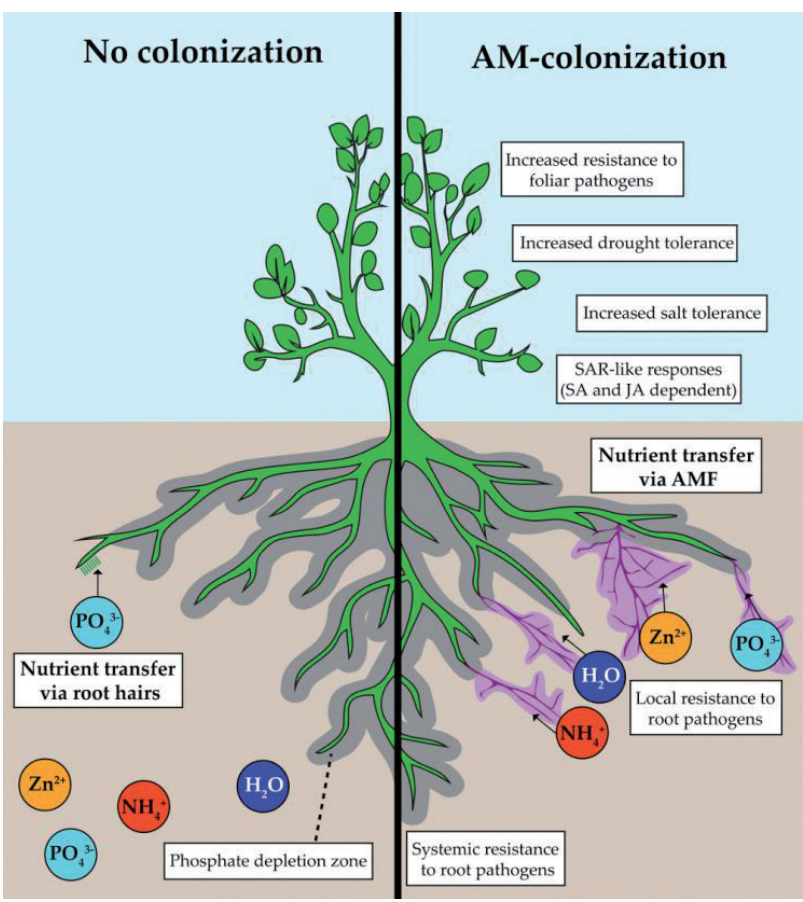

Fig. 2. Positive effects of arbuscular mycorrhizal colonization; the hyphal network (in purple) could extend beyond the phosphate depletion zone (in grey) to access a better area for phosphate absorption.

lower mobility) [10], and a lower proline, MDA, and $\mathrm{H}_{2} \mathrm{O}_{2}$ content compared with the untreated samples under water deficit conditions [33, 34]. These results provide strong evidence for improved conditions as a result of AMF, both through the plant enzyme defense system and osmotic regulatory network [33, 34].

Slopes located in more pluvial regions are affected by heavy rainfall and are frequently subjected to damage caused by rain erosion [35]. Relevant capacities of AMF, for instance enhancing soil-reinforcement of the root system and reducing leaching loss, are favorable
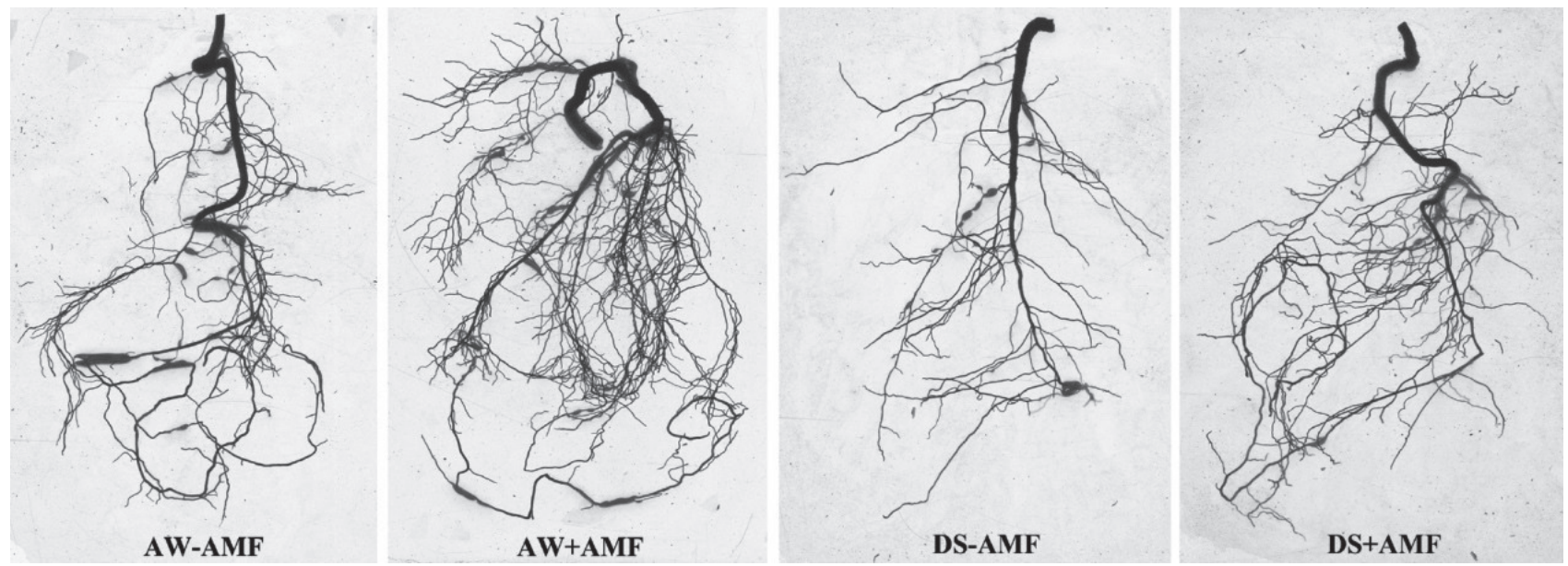

Fig. 1. Root system architectures of trifoliate orange seedlings inoculated (+AMF) with Glomus mosseae, not inoculated (-AMF), exposed to ample water (AW), or drought stress (DS). 
for soil conservation $[2,5,36]$. There is evidence that the negative impact of increased precipitation, the most typical example of which is nutrient losses, may be mitigated by AMF through their extensive hyphal network [37, 38], and this function may even be improved under high rainfall intensity [37]. Unlike the stress of heavy rainfall on the whole soil microbial group and bacterial abundance, AMF abundance increased after extreme rainfall [39], which provided evidence of the ability of AMF to maintain community stability.

Very low temperatures and frozen damage will generate relatively large effects on the stability of the substrate and are unfavorable for vegetation growth [40, 41], making it difficult to conduct SERT in high altitude and cold regions. Good symbiotic relationships between AMF and certain plants under cold climate environment is able to improve the nutritional status of hosts [42] and facilitate their growth [43, 44]. Such promotion may possibly be related to nitrate reductase activity [42] and the photosynthetic pigments contents [44], which are significantly higher in mycorrhiza than that in nonmycorrhizal roots. Surveys conducted on the QinghaiTibet Plateau showed that a variety of AMF flora also had colonization ability in cold-dominated regions [45], which made it possible to screen native AMF from high and cold regions and apply them in restoration projects after multiplication.

\section{Adaptation to Slope Chemical Stress}

A high percentage of the construction materials in SERT is eventually deposited in the substrate, changing the soil chemical properties, or interfering with nutrient cycling between plants and soil. The application of mycorrhizal technology to the restoration of chemicalcontaminated soil is the focus of current AMF research [46-48], and a reasonable scheme can be designed on the basis of advanced research results for slope ecological restoration.

In order to improve substrate stability, special bonding materials have invariably been added [3], which may change the soil $\mathrm{pH}$ along with the continued deposition of indecomposable chemical compositions and have detrimental impact on the vegetation establishment [49]. Two hypotheses explained the mechanism of the adaptation of AMF to soil $\mathrm{pH}$ : directly through the metabolic activities and secretions of hypha [46], or indirectly through changing the component of plant root exudates $[49,50]$. The preference of AMF for alkaline or neutral soil and the role of AMF in alleviating acidic soil stress had also been proved by Ouzounidou et al. [49]. In addition, the absorption of alkaline earth metal elements affected by AMF contributes to the rhizosphere $\mathrm{pH}$ change as well [51]. All these results proved the indirect effect of AMF on soil $\mathrm{pH}$ regulation.

Evidence showed that elements that would result in excessive deposition of heavy metal elements on slopes, originate mainly from highway traffic [52], rock weathering [53], and corrosion of metal materials [52].
Non-biodegradable metal materials used in restoration projects to play a reinforcing role would result in $\mathrm{Zn}$ or iron $(\mathrm{Fe})$ accumulation in soil as well [3]. Experiments proved that inoculation of AMF can promote the growth of plants under heavy metal stress such as $\mathrm{Cu}$ [47], $\mathrm{Pb}$ [53], $\mathrm{Zn} \mathrm{[48],} \mathrm{and} \mathrm{Cd} \mathrm{[54].} \mathrm{Although} \mathrm{increased} \mathrm{Cu} \mathrm{supply}$ will result in a significant decrease in the infection rate and spore density of AMF due to the strong fungal toxicity of $\mathrm{Cu}$ [55], many experiments showed the ability of AMF to promote plant growth - especially a significant increase in plant biomass and $\mathrm{P}$ uptake and immobilization of soil $\mathrm{Cu}$ by mycelia $[10,46]$. In addition to help take up $\mathrm{Zn}$ from $\mathrm{Zn}$-deficient soil, AMF can also protect plants against $\mathrm{Zn}$ toxicity under high soil $\mathrm{Zn}$ concentrations [56]. This bi-directional regulation may be attributed to a $\mathrm{Zn}$ threshold in soil, below which plant $\mathrm{Zn}$ nutrition can be improved, while above which mycorrhizal infection will decrease in order to reduce $\mathrm{Zn}$ accumulation in plants [56]. In conclusion, the roles of AMF inoculation under heavy metal stress include the following: improved plant growth [57]; improved phosphorus (P) nutrition, which may be related to the detoxification of polyphosphates to heavy metals [58]; and immobilization of heavy metals and secretion of chelates to reduce their toxicity and bioavailability [46].

\section{Resistance to Pathogenic Microbial Attack}

Due to neglect and infrequent maintenance, slope vegetation is often not treated promptly when attacked by exotic pathogens or pests. Although chemical agents have been sprayed on the damaged plants and might appear to work in the short term, the costs of manual labor, material and financial resources increase the difficulties associated with management; therefore, flexible methods still need to be developed.

AMF can offer protection to host plants against various soil-borne pathogens and pests, either through changing plant activities or changing plant endogenous regulators (Fig. 2) [4, 13, 17, 59]. The antagonistic relationships between AMF and herbivorous insects and parasites largely depend on the release of volatile organic compounds by hosts [59]. With respect to disease resistance, Wehner et al. [13] summarized the mechanism of AMF against pathogens as interference competition (direct interactions) and exploitation competition (indirect interactions). Studies have also shown that the interaction between different AMF combinations may play a good role in pathogen protection [13]. Therefore, Wehner et al. [13] suggested shifting the focus from single to multiple species of AMF assemblages and to take account of the functional groups that coexist with roots. Additionally, the interaction between AMF and pathogens makes AMF have a certain effect on biological invasion [4, 12], which can be applied to protect slope plants from invasive species, maintaining the overall beauty of slope vegetation. 


\section{Optimization of the Slope Ecological Environment}

Soil, plants and soil microbes are the three elements of slope ecological environment, and an inseparable relationship exists among them. AMF served as a special bond with them due to its improvement on soil structure and properties [14, 32], plant development [46], and microbial community [16], which strengthen the link between the three and then optimize slope environment.

\section{Effects of AMF on Soil}

As the terminologies used to describe the size and arrangement of soil solids and pores, soil aggregates are strongly associated with soil porosity and waterholding capability [60]. Thirty-five experimental results on AMF and soil aggregates have been synthesized and finally confirmed the positive contribution of AMF to the stabilization of soil aggregates [14]. The directly enhancing mechanisms of AMF is through the release of intrahyphal components from mycorrhiza and the exudation and entanglement of hyphe and particles [60]. The intrahyphal components of filamentous AMF, the most significant of which is the GRSP, would be released during turnover [60], making the hyphal network stickystring bags, and stabilizing soil aggregates around them through bonding and entanglement. Furthermore, a recent experiment in New Caledonia showed that the targeted screening of AMF could help the ecological restoration of bare slopes by their enhancement effect on soil aggregate stability [61], which further illustrates the feasibility of AMF for slope restoration.

AMF have been proven to affect soil properties, include water content [62], particle size, soil $\mathrm{pH}$, electrical conductivity, and soil enzyme activities [63], through proliferation between or on the surface of soil particles as well [15]. The soil water retention and hydraulic conductivity of AMF could help plants adapt to variations in soil moisture [15]. Inoculation with AMF would result in higher water availability due to the stronger water absorption of hypha and would make further efforts to restore the plant hydraulic status with higher soil drying rates [4, 33, 60]. Electrical conductivity, which has a positive correlation with soil moisture within a certain range, has also been found to have a clear correlation with AMF inoculation $[63,64]$. As for enzyme activities, though the impact mechanism is not yet clear, researchers have detected increases in $\beta$-glucosidase [63], catalase [45,63], urease [17], dehydrogenase [17], protease [17], peroxidas and dismutase [47], and phosphatase activities [17,63], and transient increases in catalase activity after AMF inoculation [17]. Studies also have shown a negative correlation between AMF and clay content [64], which may result in an increase in silt percentage. Those results may be due to more oxygen provided by soil with a high sand content, which can satisfy the oxygen requirement of AMF [65].

\section{Effects on Plant Growth and Development}

The promotion of plant nutrient uptake by AMF has received considerable attention over several decades, and the regulation and control mechanisms have been partially determined [46, 66, 67]. Evidence has shown that AMF could improve the uptake of $\mathrm{P}[4,32]$, nitrogen [66], potassium [66], calcium, magnesium, and trace elements, and could contribute to about 70$80 \%$ of the $\mathrm{P}$ absorbed by hosts. There has been much speculation about the mechanism [46]: 1) mycelium enlarges the absorption area of host roots [46];2) the content of organic acids in the root exudates increases after inoculation with AMF to activate $\mathrm{P}$ in the soil [68]; 3) the affinity between mycorrhizal and phosphate is greater than that between non-mycorrhizal roots and phosphate, and the critical concentration of $\mathrm{P}$ absorption in hyphe is lower than that in root as well (Fig. 2); and 4) the P transport rate in mycelia is faster than that in plant roots [4]. And following the discovery of the inducing effect of AMF on plant phosphate transporters, regulatory genes will have further information about the mechanism of AMF in promoting plant nutrition at the molecular level [57, 69].

Studies have also shown that AMF has an effect on the secretion of plant hormones [34, 70]. AMF significantly increased the content of auxin, gibberellin, and jasmonic acid in leaves and roots of plants under normal and drought stress conditions [34, 70] and decreased the contents of abscisic acid [70]. Increased hormone accumulation is associated with strigolactones secreted by plant roots and signal substances secreted by mycelia, including sulfide oligosaccharides, non-sulfide oligosaccharides and chitosan oligosaccharides [71]. AMF can also promote the metabolism of polyamines under stress and enhance plant tolerance through feedback regulation [72]. Moreover, the diversity and colonization of AMF is in turn driven by the endogenous plant hormones levels [73], and such interactions between AMF and phytohormone may result in positive regulation of plant development.

\section{Interaction with Soil Microbes}

The establishment of beneficial natural networks between AMF and other beneficial soil microbes, which resulted from various symbiotic and nonsymbiotic associations, apparently evolved during plant growth and development $[4,16,17]$.

A close relationship between symbiotic bacteria like rhizobium and AMF has been shown through dual inoculation experiments on plant yield, root colonization, disease resistance [74], P content,[4] and nodule numbers [75]. Respiratory oxidative burst homolog-mediated reactive oxygen species are considered to be vital substances that play a critical role in this symbiosis [76]. Apart from rhizobia, AMF also affects the symbiosis of plants and symbiotic actinomycetes, [4] though sometimes antagonistic effects exist between these two 
species, which may result in a detrimental effect on the host [77].

The interaction between AMF and non-symbiotic bacteria in soil, especially P- solubilizing bacteria [78], nitrobacteria and denitrobacteria [79], and some autotrophic nitrogen-fixing bacteria [77], has been verified in numerous studies. A synergistic effect of P-solubilizing bacteria and AMF in the improvement of soil-neutral phosphatase activity and $\mathrm{P}$ uptake has been proved [78], which may be beneficial for plant natural regeneration [78]. AMF abundance is positively correlated with the abundance of $\mathrm{N}_{2} \mathrm{O}$ producing bacteria and is negatively correlated with the abundance of $\mathrm{N}_{2} \mathrm{O}$-consuming bacteria, so AMF can affect the structure of soil N-nutrition-related microbial populations [77]. Unlike the inhibition of ammoniaoxidizing bacteria, soil nitrogen-fixing bacteria are usually positively affected [4], which may be due to the nitrogen sources, of which the former originates from the air while the latter is highly dependent on plant rhizosphere secretions [80].

Synergistic relationships were seen with AMF and an epiphytic fungus in terms of mutual reinforcement [4], which improved plant development and nutrient availability [4, 77]. Although the symbiotic relationship between AMF and ecto-mycorrhizal fungi had also been found $[4,48]$, this balance is not always positive, and mutual inhibition was observed between them [4]. Therefore, local microbes need to be carefully considered for AMF application in different restoration conditioins in order to avoid negative effects in practical application [2].

\section{Future Prospects for Applying AMF in Slope Ecological Restoration}

\section{Relevant Applied Research}

Significant achievements of laboratory and field experiments on AMF technology suggest unlimited potential to its application on SERT. However, this application has not been used generally. Therefore, the relationship between AMF and soil, plant, microorganism in the disturbed area provides further factual basis for feasibility. A project that validated the feasibility of AMF for slope restoration was carried out in the San Francisco River Basin, Brazil [81], which explained the role of AMF species in disturbed slopes from the perspective of soil aggregation and stability. This study also echoes the relationship between AMF and soil stability from the perspective of slope restoration. In addition, due to the particularity of the environment, the viability of AMF under engineering disturbance also calls for special emphasis to investigate its application as SERT materials. A study aimed to evaluate the tolerance of AMF population to soil disturbances found that the structure of plant mycorrhizal communities on land slopes was affected by severe soil disturbances, but AMF on landward slopes were not necessarily disturbance-sensitive even if AMF abundance increased after disturbance [82]. Kawahara et al. [82] indicated that the artificial disturbance effects on the AMF community is due to the emergence of hidden new members or a change in the microbial abundance of the whole system, and AMF colonization on land slopes is interference-resistant to a certain level. Besides, there is speculation that AMF can quickly gain an advantage not only through the hyphal network, but also through spores [82], which may be a possible explanation for the advantage brought by AMF in the early stage while no mycorrhizal structure has been formed. This is also the solution of giving artificial AMF inoculum dominance in occupying the advantage in the early recovery period so as to achieve the greatest potential.

\section{Existing Problems and Future Prospects}

Compared with laboratory research, practical difficulties are confronted with more challenges, which can be summarized as follows:

Restrictions on commercial AMF production. Due to the limitation of technology as well as costs, the existing AMF production methods are only scratching the surface of experimental needs, yet none of them is actually satisfactory for both the quantity and the quality demands of AMF inoculum required for restoration engineering [12]; 2) the storage method and quality of AMF inoculum. As inoculum of endophytic fungi, infected plant tissues must be used within their validity period to guarantee effectiveness. In addition to solid inoculum as the most widely used type [12, 83], novel formulations applied in research, such as liquid inoculum, capsule inoculum and seed coating [12], which are restricted by the cost-factors in reality, are difficult to successfully list. Many agent products on the market even usually rely on fertilizing compounds added to them for the formation of mycorrhizal symbiosis, but poor-quality products hinder the advancement of technology [81]; 3) The inoculation method in engineering application. Pot culture is easy to ensure the uniform mixing of AMF inoculum and seeds for effective mycorrhizal symbiosis in experimental studies $[34,68]$, but this method is obviously not feasible for engineering because of the huge workload and the financial resource consumption [12]; and 4) Excellent AMF effects generally occur in environmentally controlled experiments, yet in complex habitats of field application, validity and efficiency are unstable, which is the maximum limit of putting mycorrhizal technology into practical application [12, 77]. Plant selectivity and interaction with soil microbes of AMF need to be summarized within the scope of pioneer plants in restoration engineering so that determining species arrangement may become easier $[82,83]$.

Through analysis of the application environment, advantages and limitations of the application potentiality, 
the following practical and development directions of this technology are pointed out: 1) Close ties with production enterprises need to be established to form a production chain for enlarging the production scale and increasing the production efficiency of AMF inoculum; 2) Related statutes and policies on the quality standard of AMF inoculum needs be published to ensure the benefit of better-quality products; 3) An artificial inoculation system needs to be established, such as stratified spraying and coat-pelleted seed technique [3, 8, 12], which are applicable to slope engineering construction in order to reduce the economic losses caused by complex operation and develop a complete, rationally distributed maintenance management mode to guarantee sustainability; 4) The impacts of slope aspects and slope position on the AMF population require further study to indicate where optimization might be required for construction on slopes; 5) The interaction mechanism between indigenous microorganisms and AMF is to be studied further to reduce the restrictions of mycorrhizal effect under uncontrolled complex environments; 6) More experimental data on host specificity of AMF needs to be accumulated for a proprietary database of plants applied in slope ecological restoration in order to choose suitably engineered plants for a project [50]. To integrate with practice closely and to address critical issues, preliminary investigations of the characteristics of soil and microorganisms in a real engineering site should be performed for reasonable AMF and plant arrangement. In addition, AMF technology is also worth considering for SERT in some areas with severe stress, if the higher cost can yield more beneficial results.

\section{Conclusions}

The theoretical research and practical applications indicate that AMF can be used as a practical material in slope ecological restoration. Theoretically, their role in enhancing plant stress resistance, promoting plant nutrient uptake, improving soil structure, and altering the structure and composition of the soil microbial communities make them a communication channel between the three most important factors of slopes - soil, plants, and microbes - to strengthen the connection between factors, which would help with long-term slope stability. Based on basic research, existing applications had proved the positive impact of AMF on vegetation development and soil stabilization of disturbed slopes, suggesting that the application of AMF may acquire a higher target of restoration. Moreover, in order to increase the practical feasibility of introducing mycorrhizal technology in slope restoration, further detailed experiments should be carried out to explore the ecological relevance of AMF and a simpler propagation method, finding out basic mechanisms and experience according to appropriate combinations of microbes and plant species in different types of regions. Combining AMF with traditional restoration methods and applying them in large-scale practical application are of great significance to technological innovation of slope ecological restoration. It is essential to thoroughly research the interaction system among the microbes, plants and soil and the mechanisms involved, so that we can develop a new efficient method to attain satisfactory results for slope ecological restoration.

\section{Acknowledgements}

We acknowledge support from the National Key R\&D Program of China (grant No. 2017YFC0504902) and the National Natural Science Foundation of the People's Republic of China (grant No. 51678348). We thank LetPub (www.letpub.com) for its linguistic assistance during the preparation of this manuscript.

\section{Conflict of Interest}

The authors declare no conflict of interest.

\section{References}

1. SHAO Q., GU W., DAI Q.Y., MAKOTO S., LIU Y. Effectiveness of geotextile mulches for slope restoration in semi-arid northern China. Catena, 116, 1, 2014.

2. YANG Y., YANG J., ZHAO T., HUANG X.W., ZHAO P. Ecological restoration of highway slope by covering with straw-mat and seeding with grass-legume mixture. Ecological Engineering, 90, 68, 2016.

3. XU W.N. Theory and Practice of Ecological Protection Technology for Vegetation Concrete, $3^{\text {rd }}$ ed.; China Water and Power Press, Beijing, China, Volume 2, 55, 2012.

4. DIAGNE N., DIOUF D., SVISTOONOFF S., KANEA A., NOBA K., FRANCHE C., BOGUSZ D., DUPONNOIS R. Casuarinws2a in Africa: distribution, role and importance of arbuscular mycorrhizal, ectomycorrhizal fungi and Frankia on plant development. Journal of Environmental Management, 128, 204, 2013.

5. MARTIN D.M. Ecological restoration should be redefined for the twenty-first century. Restoration Ecology, 25, 668, 2017.

6. CATHERINE J., JEREMY M., CHRISTOPHER R. Trade-Offs in Arbuscular Mycorrhizal Symbiosis: Disease Resistance, Growth Responses and Perspectives for Crop Breeding. Agronomy, 7, 75, 2017.

7. MEI X.M., MA L., ZHU Q.K., WANG S., ZHANG D., WANG Y. Responses of soil moisture to vegetation restoration type and slope length on the loess hillslope. Journal of Mountain Science, 15, 548, 2018.

8. ZHAO B.Q., XIA Z.Y., XU W.N., YANG S., XIA D.,WANG Z.G. Summary of Research on Slope Ecological Restoration Technology in Engineering Disturbance Zone. Water Conservancy and Hydropower Technology, 48, 130, 2017.

9. CHEN S., AI X., DONG T., LI B.B., LUO R.H., AI Y.W., CHEN Z.Q., LI C.R. The physico-chemical properties and structural characteristics of artificial soil for cut slope restoration in Southwestern China. Scientific Reports, 6, 20565, 2016. 
10. WU Q.S., SRIVASTAVA A.K., ZOU Y.N. AMF-induced tolerance to drought stress in citrus: A review. Scientia Horticulturae, 164 (17), 77, 2013.

11. LENOIR I., FONTAINE J., SAHRAOUI A.L.H. Arbuscular mycorrhizal fungal responses to abiotic stresses: A review. Phytochemistry, 123, 4, 2016.

12. VOSATKA M., LATR A., GIANINAZZI S., ALBRECHTOVA J. Development of arbuscular mycorrhizal biotechnology and industry: current achievements and bottlenecks. Symbiosis, 58, 29, 2012.

13. WEHNER J., ANTUNES P.M., POWELL J.R., MAZUKATOW J., RILLIG M.C. Plant pathogen protection by arbuscular mycorrhizas: A role for fungal diversity. Pedobiologia, 53, 197, 2010.

14. LEIFHEIT E.F., VERESOGLOU S.D., LEHMANN A., MORRIS E.K., RILLIG M.C. Multiple factors influence the role of arbuscular mycorrhizal fungi in soil aggregation-a meta analysis. Plant and Soil, 374 (1), 523, 2014.

15. DOROSTKAR V., AFYUNI M., KHOSHGOFT A.H., MOSADDEGHI M.R., REJALI F. Subcritical soil hydrophobicity in the presence of native and exotic arbuscular mycorrhizal species at different soil salinity levels. Archives of Agronomy and Soil Science, 62:1, 2015.

16. MIRANSARI M. Plant, Mycorrhizal Fungi, and Bacterial Network. Plant signaling: Understanding the molecular crosstalk, 8, 315, 2014.

17. YE S., YANG Y., XON G., WANG Y.T., RUAN L., YE G.G. Studies of the Italian ryegrass-rice rotation system in southern China: Arbuscular mycorrhizal symbiosis affects soil microbes and enzyme activities in the Lolium mutiflorum L. rhizosphere. Applied Soil Ecology, 90, 26, 2015.

18. MCELROY M.T., RIEKE P.E., MCBURNEY S.L. Utilizing plant growth regulators to develop accost efficient management system for roadside vegetation. Retarders, 1984.

19. CANDA Y. Greening Engineering Technology, $2^{\text {rd }}$ ed.; Moribei Publishing, Tokyo, Japan, 1979.

20. SUI M.H. Study on the structural stability of ecological slope protection by spraying grass with anchor-geonet cushion on high and steep rock slope. Qingdao University of Technology, 2012.

21. KOH J.H., HUR Y.J., LEE Y.G., KIM N.C. A Study on the Use of a Continuous Fiber Soil Reinforcement System to Revegetate a Cut Slope. Journal of the Korean Institute of Landscape Architecture, 13, 20, 2010.

22. STIPHO A.S. On the engineering properties of salina soil. Quarterly Journal of Engineering Geology and amp;Hydrogeology, 18, 129, 1985.

23. Soil Microbial Features on Different Ecological Protection Technologies. Proceedings of 2011 International Symposium on Water Resource and Environmental Protection. VOL.03. 2011

24. ZHU H., RUAN D.H., QIN S.Y. Vertical Ecological Restoration Technique for the High-Steep Rock Slopes of Highway in Mountainous Area. Geosynthetics in Civil and Environmental Engineering. Springer Berlin Heidelberg, 2008.

25. TRON S, RAYMOND P. Analysis of root reinforcement of vegetated riprap. Egu General Assembly Conference, 2014.

26. QIN X. Research on fast ecological restoration technology of high and steep rocky slope of highway. Green Energy \& Sustainable Development I: International Conference on Green Energy \& Sustainable Development. 2017.
27. ZHANG W.J., LI R., CHEN J., XU W.N., LI W., AI Y.W. Enzyme activity and microbial biomass availability in artificial soils on rock-cut slopes restored with outside soil spray seeding (OSSS): Influence of topography and season. Journal of Environmental Management, 211, 28, 2018.

28. CHOON N.K. Ecological restoration and revegetation works in Korea. Landscape and Ecological Engineering, 1, 77, 2005.

29. CHRISTOPHE M., FRASIER C.L., BAKOLIMALALA R., EDWARD E.L. Ecological Restoration and Reforestation of Fragmented Forests in Kianjavato, Madagascar. International Journal of Ecology, 1, 2013.

30. TARIQ S., ALAM M.M., MONDAL M.E.A., VOSHAL V. Slope mass rating and kinematic analysis of slopes along the national highway-58 near Jonk, Rishikesh, India. Journal of Rock Mechanics and Geotechnical Engineering, 7, 600, 2015.

31. PABLO G.P., SOLIVERES S., MARSTRE F.T., ESCUDERO A., MONROY A.C., VALLADARESA F. Dominant plant species modulate responses to hydroseeding, irrigation and fertilization during the restoration of semiarid motorway slopes. Ecological Engineering, 36, 1290, 2010.

32. BI Y.L., QIU L., ZHAKYPBEK Y., JIANG B., CAI Y., SUNA H. Combination of plastic film mulching and AMF inoculation promotes maize growth, yield and water use efficiency in the semiarid region of Northwest China. Agricultural Water Management, 201, 278, 2018.

33. AMIRI R., NIKBAKHT A., ETEMADI N. Alleviation of drought stress on rose geranium (Pelargonium graveolens (L.) Herit.) in terms of antioxidant activity and secondary metabolites by mycorrhizal inoculation. Scientia Horticulturae, 197, 373, 2015.

34. TYAGI J., VARMA A., PUDAKE R.N. Evaluation of comparative effects of arbuscular mycorrhiza (Rhizophagus intraradices) and endophyte (Piriformospora indica) association with finger millet (Eleusine coracana) under drought stress. European Journal of Soil Biology, 81, 1, 2017.

35. KIM J., KIM Y., JEONG S., HONG M. Rainfall-induced landslides by deficit field matric suction in unsaturated soil slopes. Environmental Earth Sciences, 76, 808, 2017.

36. MARTINEZ E.A., DRIGUEZ H., BÉCARD G., DÉNARIÉ J. Fungal lipochitooligosaccharide symbiotic signals in arbuscular mycorrhizal. Nature, 469, 58, 2011.

37. MARTINEZ L.B., DEYN G.B., PUGNAIRE F.I., KOTHAMASI D., HEIJDEN M.G.A. Symbiotic soil fungi enhance ecosystem resilience to climate change. Global Change Biology, 23, 5228, 2017.

38. CAVAGNARO T.R., BENDER S.F., ASGHARI H.R., MARCEL G.A. The role of arbuscular mycorrhizas in reducing soil nutrient loss. Trends in Plant Science, 20, 283, 2015.

39. BARNES C.J., VAN d G.C.J., MCNAMARA N.P., ROWE R., BENDING G.D. Extreme rainfall affects assembly of the root-associated fungal community. New Phytologist, 220, 172, 2018.

40. CHEN X., LIU J.K., XIE N., SUN H.J. Probabilistic analysis of embankment slope stability in frozen ground regions based on random finite element method. Science in Cold and Arid Regions, 7, 354, 2015.

41. XU H., LI T.B., CHEN J.N., LIU C.N., ZHOU X.H., XIA L. Characteristics and applications of ecological soil substrate for rocky slope vegetation in cold and highaltitude areas. Science of The Total Environment, 609, 446, 2017. 
42. LIU N., CHEN X., SONG F., LIU F.L. Effects of Arbuscular Mycorrhiza on Growth and Nutrition of Maize Plants under Low Temperature Stress. Philippine Agricultural Scientist, 99, 246, 2016.

43. MA J., JANOUŠKOVÁ M., LI Y., YU X., YAN Y., ZOU Z., HE C. Impact of arbuscular mycorrhizal fungi (AMF) on cucumber growth and phosphorus uptake under cold stress. Functional Plant Biology, 42, 1158, 2015.

44. LATEF A.A.H.A., HE C.X. Arbuscular mycorrhizal influence on growth, photosynthetic pigments, osmotic adjustment and oxidative stress in tomato plants subjected to low temperature stress. Acta Physiologiae Plantarum, 33, 1217, 2011.

45. LIU Y., HE J., SHI G., FENG H. Diverse communities of arbuscular mycorrhizal fungi inhabit sites with very high altitude in Tibet Plateau. Fems Microbial Ecology, 78, 355, 2011.

46. WANG F.Y., LIN X.G. Xiangui Arbuscular Mycorrhiza and Soil Rehabilitation. Science Press, Beijing, 2015.

47. YANG G., KE L.U., ZHU G.L., PAN M.X., DONG L.J., LUO J., MO Y.W. Effect of arbuscular mycorrhizal fungus Glomus mosseae on photosynthesis and antioxidation enzyme activities in Actractylodes macrocephala seedlings under copper stress. Plant Physiology Journal, 54, 618, 2018.

48. GANGE A.C., GANE D.R.J., CHEN Y., GONG M.Q. Dual colonization of Eucalyptus urophylla S.T. Blake by arbuscular and ectomycorrhizal fungi affects levels of insect herbivore attack. Agricultural and Forest Entomology, 7, 253, 2015.

49. OUZOUNIDOU G., SKIADA V., PAPADOPOULOU K., STAMATIS N., KAVVADIAS V. Effects of soil $\mathrm{pH}$ and arbuscular mycorrhiza (AM) inoculation on growth and chemical composition of chia (Salvia hispanica L.) leaves. Brazilian Journal of Botany, 38, 487, 2015.

50. MATSUBARA Y., ISHIGAKI T., KOSHIKAWA K. Changes in free amino acid concentrations in mycorrhizal strawberry plants. Scientia Horticultura, 119, 392, 2009.

51. DOUBKOVÁ P., SUDA J., RADKA S. The symbiosis with arbuscular mycorrhizal fungi contributes to plant tolerance to serpentine edaphic stress. Soil Biology and Biochemistry, 44, 56, 2012.

52. WEI B., YANG L. A review of heavy metal contaminations in urban soils, urban road dusts and agricultural soils from China. Microchemical Journal, 94, 99, 2010.

53. YANG Y., HAN X., YAN L., GHOSH A., CHEN J., TANG M. The Combined Effects of Arbuscular Mycorrhizal Fungi (AMF) and Lead $(\mathrm{Pb})$ Stress on $\mathrm{Pb}$ Accumulation, Plant Growth Parameters, Photosynthesis, and Antioxidant Enzymes in Robinia pseudoacacia L. Plos One, 10, e0145726, 2015.

54. HASHEM A., ALLAH E.F.A., ALQARAWI A.A., EGAMBERDIEVA D. Bioremediation of adverse impact of cadmium toxicity on Cassia italica, Mill by arbuscular mycorrhizal fungI. Saudi Journal of Biological Sciences, 23, 39, 2016.

55. CORNEJO P., PÉREZ T.J., MEIER S., VALDERAS A., BORIE F., AGUILAR A.C., FERROL N. Copper compartmentalization in spores as a survival strategy of arbuscular mycorrhizal fungi in $\mathrm{Cu}$-polluted environments. Soil Biology and Biochemistry, 57, 925, 2013.

56. CAVAGNARO T.R. The role of arbuscular mycorrhizas in improving plant zinc nutrition under low soil zinc concentrations: a review. Plant and Soil, 304, 315, 2018.

57. YANG S.Y., GRONLUND M., JAKOBSEN I., GROTEMEYER M.S., RENTSCH D., MIYAO A.,
HIROCHIKA H., KUMAR C.S., SUNDARESAN V., SALAMIN N., CATAUSAN S., MATTES N., HEUER S., PASZKOWSKIA U. Nonredundant Regulation of Rice Arbuscular Mycorrhizal Symbiosis by Two Members of the Phosphate Transporterl Gene Family. The Plant Cell, 24, 4236, 2012.

58. YAO Q., YANG R., LONG L., ZHU H.H. Phosphate application enhances the resistance of arbuscular mycorrhizae in clover plants to cadmium via, polyphosphate accumulation in fungal hyphae. Environmental and Experimental Botany, 108, 63, 2014.

59. RASMANN S., BENNETT A., BIERE A., KARLEY A., GUERRIERI E. Root symbionts: Powerful drivers of plant above-and belowground indirect defenses. Insect Science, 24, 947, 2017.

60. DAI J., HU J., ZHU A., BAI J.F., WANG J.H., LIN X.G. No tillage enhances arbuscular mycorrhizal fungal population, glomalin-related soil protein content, and organic carbon accumulation in soil macroaggregates. Journal of Soils and Sediments, 15, 1055, 2015.

61. DEMENOIS J., REY F., STOKES A., CARRICONDE F. Does arbuscular and ectomycorrhizal fungal inoculation improve soil aggregate stability? A case study on three tropical species growing in ultramafic Ferralsols. Pedobiologia, 64, 8, 2017.

62. WANG S., WANG X., OUYANG Z. Effects of land use, climate, topography and soil properties on regional soil organic carbon and total nitrogen in the Upstream Watershed of Miyun Reservoir, North China. Journal of Enviroment Science, 24, 387, 2012.

63. ZHANG H., WU X., LI G., QIN P. Interactions between arbuscular mycorrhizal fungi and phosphate-solubilizing fungus (Mortierella sp.) and their effects on Kostelelzkya virginica growth and enzyme activities of rhizosphere and bulk soils at different salinities. Biology and Fertility of Soils, 47, 543, 2011.

64. ALGUACIL M.D.M., TORRES M.P., NAVARRO A.M., ROLDÁN A. Soil characteristics driving arbuscular mycorrhizal fungi communities in semiarid Mediterranean soils. Applied and Environmental Microbiology, 82, 3348, 2016.

65. TORRECILLAS E., DEL M.A.M., ROLDAN A., DÍAZ G., NAVARRO A.M., TORRES M.P. Modularity Reveals the Tendency of Arbuscular Mycorrhizal Fungi To Interact Differently with Generalist and Specialist Plant Species in Gypsum Soils. Applied and Environmental Microbiology, 80, 5457, 2014.

66. VERZEAUX J., HIREL B., DUBOIS F., LEA P., TÉTU T. Agricultural practices to improve nitrogen use efficiency through the use of arbuscular mycorrhizae: basic and agronomic aspects. Plant Science An International Journal of Experimental Plant Biology, 264, 48, 2017.

67. ZHANG H., WEI S., HU W., XIAO L.M., TANG M. Arbuscular Mycorrhizal Fungus Rhizophagus irregularis Increased Potassium Content and Expression of Genes Encoding Potassium Channels in Lycium barbarum. Frontiers in Plant Science, 8, 440, 2017.

68. REN L.X., ZHANG N., WU P., HUO H.W., XU G.H., WU G.P. Arbuscular mycorrhizal colonization alleviates Fusarium wilt in watermelon and modulates the composition of root exudates. Plant Growth Regulation, 77, 77, 2015.

69. JAVOT H., PUMPLIN N., HARRISON M.J. Phosphate in the arbuscular mycorrhizal symbiosis: transport properties and regulatory roles. Plant Cell and Environment, 30, 310, 2007. 
70. ETEMADI M., GUTJAHR C., COUZIGOU J.M., ZOUINE M., LAURESSERGUES D., TIMMERS A., AUDRAN C., BOUZAYEN M., BÉCARD G., COMBIER J.P. Auxin Perception Is Required for Arbuscule Development in Arbuscular Mycorrhizal Symbiosis. Plant Physiology, 166, 281, 2014.

71. MAILLET F., POINSOT V., ANDRÉ O., HAOUY A., GUEUNIER M., CROMER L., GIRAUDET D., FORMEY D., NIEBEL A., MARTINEZ E.A., DRIGUEZ H., BÉCARD G., DÉNARIÉ J. Fungal lipochitooligosaccharide symbiotic signals in arbuscular mycorrhizal. Nature, 469, 58, 2011.

72. SALLOUM M.S., MENDUNI M.F., BENAVIDES M.P., LARRAURI M., LUNA C.M., SILVENTE S. Polyamines and flavonoids: key compounds in mycorrhizal colonization of improved and unimproved soybean genotypes. Symbiosis, 76, 265,2018.

73. FOO E., ROSS J.J., JONES W.T. Plant hormones in arbuscular mycorrhizal symbioses: an emerging role for gibberellins. Ann Bot, 111, 769, 2013.

74. GAO P., GUO Y., LI Y. Effects of dual inoculation of AMF and rhizobium on alfalfa (Medicago sativa) root rot caused by Microdochium tabacinum. Australasian Plant Pathology, 47, 195, 2018.

75. ERMAN M., DEMIR S., OCAK E., TÜFENKÇI S., OĞUZ F., AKKÖPRÜ A. Effects of Rhizobium, arbuscular mycorrhiza and whey applications on some properties in chickpea (Cicer arietinum L.) under irrigated and rainfed conditions 1-Yield, yield components, nodulation and AMF colonization. Field Crops Research, 122, 14, 2011.

76. ARTHIKALA M.K., NAVA N., QUINTO C. Effect of Rhizobium and arbuscular mycorrhizal fungi inoculation on electrolyte leakage in Phaseolus vulgaris roots overexpressing RbohB. Plant Signaling and Behavior, 2015.

77. WEI L.L., LU C.Y., DING J., YU S. Nutrient Exchange and Regulation in Plant-Soil System Involved by Arbuscular Mycorrhizal Fungi. Journal of Ecology, 36, 4233, 2016.

78. GHOBAD S., REZA A.M., REZA C.M., JUERGEN F. Effect of Different Fertilizing Systems on Seed Yield and Phosphorus Uptake in Annual Medics under Dryland Farming Conditions. Notulae Botanicae Horti Agrobotanici Cluj-Napoca, 39, 191, 2011.

79. CAVAGNARO T.R. The role of arbuscular mycorrhizas in improving plant zinc nutrition under low soil zinc concentrations: a review. Plant and Soil, 304, 315, 2018.

80. BÜRGMANN H., MEIER S., BUNGE M., WIDMER F., ZEYER J. Effects of model root exudates on structure and activity of a soil diazotroph community. Environmental Microbiology, 7, 1711, 2005.

81. SCOTTI M.R., KIMURA A.C. Soil aggregation and arbuscular mycorrhizal fungi as indicators of slope rehabilitation in the São Francisco River basin (Brazil). Soil and Water Research, 11, 114, 2016.

82. KAWAHARA A., EZAWA T. Characterization of arbuscular mycorrhizal fungal communities with respect to zonal vegetation in a coastal dune ecosystem. Oecologia, 173, 533, 2013.

83. CHEN B.D., YU M., HAO Z.P., XIE W., ZHANG $X$. Advances in application technology of arbuscular mycorrhizal fungi. Journal of Applied Ecology, 30, 1035, 2018. 